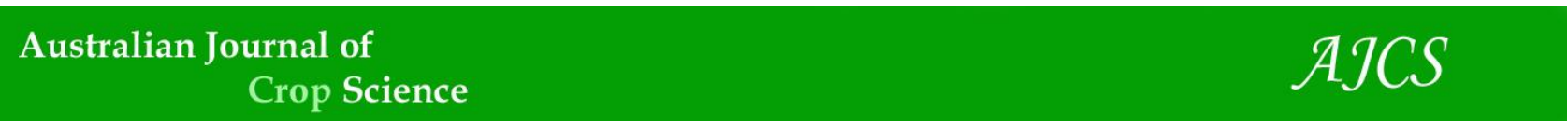

AJCS 15(07):965-969 (2021)

ISSN:1835-2707

doi: 10.21475/ajcs.21.15.07.p3285

\title{
Brazilian forest code: Advances and setbacks
}

\section{Deivid Araujo Magano ${ }^{1}$, Ivan Ricardo Carvalho ${ }^{1}$, Danieli Jacoboski Hutra ${ }^{1}$, Murilo Vieira Loro ${ }^{1}$, Marta Tremea ${ }^{1}$, Valéria Escaio Bubans ${ }^{2}$, Francine Lautenchleger ${ }^{3}$, Luiz Leonardo Ferreira ${ }^{4}$, Maicon Roberto Ribeiro Machado ${ }^{5}$, Joaquim Almério Jerónimo ${ }^{6}$}

\author{
${ }^{1}$ Universidade Regional do Noroeste do Estado do Rio Grande do Sul, ljuí, RS, Brasil \\ ${ }^{2}$ Universidade Federal de Santa Maria, Santa Maria, RS, Brasil \\ ${ }^{3}$ Universidade Estadual do Centro-Oeste (Unicentro), Guarapuava, RS, Brasil \\ ${ }^{4}$ Centro Universitário de Mineiros, Mineiros, Goiás, Brasil \\ ${ }^{5}$ Universidade Federal de Pelotas, Capão do Leão, RS, Brasil \\ ${ }^{6}$ Universidade Licungo- Moçambique
}

*Corresponding author: carvalho.irc@gmail.com

\begin{abstract}
In a scenario of expansion of agricultural frontiers, based on the production of grain and other commodities, Brazil today lives in a privileged position when it comes to the production and productivity of various agricultural crops and livestock. However we can see that developments in the legislative system often do not keep pace with anthropic action, which makes the degradation of the natural environment potentially disturbing. The evolution in jurisprudence has to occur concisely and quickly based on landscape parameters, and from the perspective of the technique, with a holistic behavior focused on the actions of preservation and conservation of natural resources. Forests are indispensable systems in the process of 'water generation', contributing significantly to the dynamics of the hydrological cycle, a complex and fundamental mechanism for the maintenance and regulation of life on earth. In this sense, the objective of this article is to explain some environmental, technical and legislative aspects related to the Forest Codes that were in force in Brazil, analyzing its historical relevance, flaws and finally major changes. Its preparation was based on articles, books and materials available online from the available knowledge bases. A broad revision was carried out including the Magna Carta in addition to the laws that deal with the Brazilian Forest Code, in its three versions of 1934, 1965 and 2012. As articulated considerations it can be verified that despite the evolution in the form of proposition of the current law, some modifications still need to be made, considering that the current Forest Code contains residual political and economic sequelae that neglect the socio-environmental character, and that even after the adoption of its latest version, severe damage is still being caused to the natural environment, which requires greater commitment from regulators to enforce legislation.
\end{abstract}

Keywords: biodiversity; conservation; sustainable management; forests; legislation.

Introduction

The history of humanity reflects an evolution in all aspects of civilization, and the creation of norms and rules of conduct is crucial for maintaining order (PILLA, 2009). The peoples of Mesopotamia established one of the earliest written codes of humanity - The Code of Hammurabi - which was based on precepts of a vengeful religious and moral nature (Aquino et al., 1995), which was the first attempt to establish legal norms of conduct, so that transgressions committed were properly judged for the time, based on the principle of an eye for an eye, a tooth for a tooth (GUIMARÃES, 2006).

Fortunately, the case law that according to De Plácido e Silva (2003) is derived from the conjugation of the terms, in Latin, jus (Law) and prudentia (wisdom), by what is understood as the Science of Law viewed with wisdom, or simply, the law applied wisely. In modern times, jurisprudence is understood as wise interpretation and application of laws to all concrete cases submitted to the judgment of justice. That is, the habit of interpreting and applying the laws to concrete facts, so that the causes can be decided. In this sense, jurisprudence is not formed by isolated decisions, but after a series of decisions in the same direction. This noticeable evolution becomes evident when we evaluate the most diverse legislative areas. Noll (2009, p.1) addresses the theme as follows:

"Men's history has always marked that there is a past, a present and a future. Even when stable paradigms in the various fields of knowledge succumb to speed and the unexpected, it seems reasonable to assume that these three portions of time will still and always be consistent. The law has always been made to conform future acts, not past tenses. This seemingly simplistic understanding prevails from the earliest times and forms the basis of Brazilian law. It is based on the natural reason for things. Law, as a primordial instrument of regulation of social relations, could not be immune to the constant evolution of society. Therefore, the replacement of Natural Law with Positive Law aimed precisely at responding to these new demands, and accompanies these developments."

With regard to environmental law, the changes have been extremely pronounced. The environmental issue in recent years has become one of the most relevant themes, since the 
quality of life and people's own life are directly associated with a balanced environment (FARIAS, 2002) and directly linked to the concept of sustainability, which is the conservation or maintenance of resources for future generations (LIMA, 1997).

The acceleration in recent years of globalization ${ }^{1}$, the process of integration of the economies and societies of the various countries, as well as uncontrolled population growth, increased the production and consumption of industrialized products, which made the exploitation of natural resources reach alarming levels (SIMONETTI et al., 2011). That is why legislation around the world has begun to focus on protecting ecosystems in order to establish guidelines to ensure the wellbeing of society and the generations to come.

In Brazil we have witnessed an intense debate about the Forest Code, which essentially discusses the future of the situation of the Brazilian flora, its impacts on anthropic activity and the consequences of decisions based on political interests, on the environmental, social and economic dimension. These clashes generated a series of impasses between environmentalists, congressmen and ruralists (SILVA et al., 2011).

${ }^{1}$ For Milton Santos (1996, p. 270), globalization is a process in which geographic constraints (and their vectors of time and space) on social, economic, political and cultural processes are diminished, a reduction on which individuals are becoming more aware. Understanding this process extends primarily around two main classes of phenomena, which became increasingly significant, especially in the second half of the $20^{\text {th }}$ century. On the one hand, the emergence of an increasingly globalized economy, founded on new systems of production, finance and consumption and, on the other hand, the idea of a global culture.

The aim of this paper is to approach some environmental, technical and legislative aspects related to the forest codes that were in force in Brazil, analyzing its historical relevance, inconsistencies and finally major changes.

The awakening of legislation - The Forest Code of 1934.

Since the eighteenth century, Brazilian naturalists, thinkers and eminent politicians had been aware of the fact that forests and other forms of native vegetation had functions other than wood suppliers. The relationship between forest preservation and the water cycle (rainfall, runoff velocity, infiltration, maintenance of sources), as well as between deforestation and erosion/siltation of water bodies, were evident at that time, even before the emergence of the Biological sciences and Ecology, which only confirmed what empiricism already pointed out.

Amid the strong expansion of cotton and coffee, the first Forest Code emerged in 1934. Especially in the Southeast, pushed by plantations, forests were increasingly distant from cities, making it difficult and expensive to transport firewood (AHRENS, 2003). Thus, the legislation aimed to prevent the negative social and political effects caused by the price increase, the lack of firewood, ensuring the popularity of the new regime, introduced with the 1930 Revolution.

Federal Decree no. 23793/1934 was prepared with the cooperation of several naturalists, many of whom were already concerned at the time with the conservation of the basic functions of natural ecosystems and aware of the importance of conserving all types of native vegetation and not just those that could offer firewood.

However, at the time as the main energy source was coal, the solution adopted by the 1934 Forest Code was to force landowners to keep $25 \%$ of their property area with the original forest cover. It was called the fourth part. However, there was no guidance on which area (river or other) in which the forest should be preserved. The law even encouraged the total removal of native forests as long as at least $25 \%$ of wood reserves were replanted. In this sense, it did not matter the species or the variety of trees, but only the guarantee of wood production for firewood and coal. But despite some inconsistencies, FD n. 23793/1934 also showed environmental preservation bias by creating the figure of socalled protective forests to ensure the health of rivers and lakes and risk areas (steep slopes and dunes). This concept later gave rise to Permanent Preservation Areas (PPA), also located in rural real estate.

Chapter I of this first forest code thus stated:

"Art. 1 - Forests existing in the national territory, taken together, are of common interest to all inhabitants of the country, exercising the property rights with the limitations that the laws, in general, and especially in this code, establish."

"Art. 2 - The provisions of this Code apply to forests as well as other recognized forms of vegetation of utility to the lands they cover."

In this sense, this legal diploma guaranteed that the forests considered as a whole constituted a good of common interest to all the inhabitants of the country, warning that the whole society should appreciate them as an integral part of the natural landscape, and where it refers to this natural landscape, it shows the legislator's concern with the increasing degradation that was already occurring in the Brazilian forest heritage (AHRENS, 2003).

In the scenario of the time, coffee growing, cotton production and sugarcane production were advancing to replace native vegetation. In virtually every country, forestry was purely extractive. States such as Paraná and Santa Catarina were rapidly depleting Araucaria stocks. The conclusion was then reached that it was explicitly necessary to reformulate the forest code, as degradation rates became chaotic. As a result, the government made an intervention, materialized by the edition of the Forest Code creating the so-called " new " Forest Code of 1965, which from the point of view of coherence, ends up generating more criticism as the term itself succumbs to modifications in the forthcoming environmental scenario.

\section{The "New" Brazilian Forest Code}

Sanctioned on September 15, 1965, through the publication of Law no. 4,771, the "new" Forest Code is beginning to make some major changes to the instrument that it has up to now. The first news in this novo "new" Forest Code is already shown in the edition of article 1 in its caput that reads the new wording:

Art. 1 - Forests existing in the national territory and other forms of vegetation, recognized as useful to the lands they cover, are assets of common interest to all inhabitants of the country, exercising the property rights with the limitations that the law in general and especially this law establishes.

It is clear that the legislator tacitly, restrictively and univocally refers to natural forests, thereby excluding planted forests. Strict wording avoids the dubious interpretation that could be verified in the 1934 Forest Code.

To these planted forests, Article 12 brings a special wording, because in the light of legal knowledge, it is allowed to the owners reap the rewards of their own investment, and thus states: 
Art. 12 - In planted forests, not considered permanent preservation, the extraction of firewood and other forest products or the manufacture of coal is free. In other forests, it will depend on a norm established by an act of the federal or state government in compliance with the prescriptions dictated by the technique and local peculiarities.

However, despite this notorious rigor proposed in the initial articles that make up the new forest code, there is some controversy about the feasibility of technical requirements that some authors disagree with the technique addressed in article 12 (METZGER, 2010). According to METZGER, (2010) the main doubts are related to: $i)$ the widths of Permanent Preservation Areas (PPA); ii) the extension of the Legal Reserve (LR) in the different Brazilian biomes; iii) the need to separate LR from PPA, and to maintain LR with native species; and iv) the possibility of grouping the LRs of different owners into larger fragments.

Over time, interventions were made in the original 1965 document, and additions to it were added, since as the scenario changes, it is up to legislators to insert new ways of containing the possible duality of interpretations, as landscape changes induce stiffening. (and often flexibility) to the laws, before the legal environment. In this regard, a paragraph was added to article 1 , proposed and sanctioned by provisional measure no. 2,080, of May 17, 2001, to the aforementioned code that reports:

$\$ 1$ - Actions or omissions contrary to the provisions of this Code in the use and exploitation of forests shall be considered as harmful use of the property, applying to this case the summary procedure provided for in art. 275, item II, of the Code of Civil Procedure.

In Law, the Precautionary Principle is referred to as "lack of scientific certainty" due to insufficient scientific information and knowledge about the extent of the potential adverse effects of a living modified organism on the conservation and sustainable use of biological diversity, taking also into account the risks to human health in order to avoid or minimize these potential adverse effects on the environment at an economically acceptable cost (Costa \& Costa, 2008).

In this "new" Forest Code, sanctions are emphasized and propose the compensation of legal reserve areas, which until now had not been commented, citing that it should be carried out in the same ecosystem and in the same or closer microbasin, or the closest of where deforestation occurred. According to this official decree, the National Environment Council has the power to regulate the removal of native vegetation from PPAs and LRs for up to $50 \%$ of the property of the legal Amazon, as it was foreseen the planting of exotic species in the LR allowed temporarily.

It is observed today that autopoiesis ${ }^{2}$ practically does not exist in natural systems, due to the great anthropic intervention on natural processes, so that its harmful exploitation has led to the total exhaustion of resources. Regarding the regeneration and restoration of PPA vegetation along the rivers, a distance of $\mathbf{3 0}$ meters in rivers up to 10 meters wide was listed, and they were accounted for from the larger (seasonal) bed, regardless of location.

Soares-Filho (2012, p. 2) highlights the following premise:

"The conflict between the need for increased agricultural production and the conservation of our extensive forests has created political pressure to revise the Brazilian Forest Code, which governs environmental conservation on private properties. The proposal for a new code, more flexible or less demanding, has been debated for more than a decade in the Brazilian congress and within society."
Corroborating the issue addressed Costa \& Oliveira (2013), establish the structure of participatory elements in the decision-making in a given environmental event, in relation to the technique to be applied, and in the center of a triad interposed by the technique are interspersed the environmental, social and economic scopes. It should be noted that as much as the 1965 Forest Code, after its various editions until 2012, has seen a greater punitive bias, political and economic interests often outweigh social and environmental interests.

Changing scenarios is primarily responsible for changes in environmental legislation. Today Brazil can be considered an agricultural fortress, producing and exporting the main agricultural commodities in the world, with capacity to expand their productivity potentials, which justifies the advance of the production area. The big challenge these days is precisely to do more with less, as the percentage of arable land decreases each year, resources are becoming scarcer and haunting the trend, which indicates an increase in the global population, with 9 billion inhabitants on the planet by 2050 (FAO, 2013).

${ }^{2}$ The term autopoiesis, according to Édis Milare (2005, p. 1059), is the term used in New Biology to designate both the ability and the process that living beings possess to selfbuild/reconstruct according to their " patterns of internal organization ". It is related to the concepts of 'living system' and 'web', which are used to demonstrate that the vital phenomenon develops in a systemic way and its elements are linked together. This goes for both the cell and whole organisms, which contain all the information of what will be, including flexibility and creativity to deal with unforeseen events. Life tends to perpetuate and expand as long as the process is not interrupted and organizational standards are maintained.

\section{And what changes with the 2012 forest code?}

After intense discussion, disagreements and popular manifestations, on May 28, 2012, Law no. 12651/2012, amending Laws no. 6,938 of August 31, 1981, of December 19,1996 , and 11,428 of December 22, 2006; repealing Laws no. 4,771, of September 15, 1965 and 7,754, of April 14, 1989, and Provisional Measure 2,166-67, of August 24, 2001, after 12 vetoes and 32 modifications to the original wording is sanctioned the most current version of the Forest Code.

The Law no. 12.651/2012 becomes an innovative legislation, as it seeks to understand that the official environmental requirements fall on a country with 500 years of history, and for this purpose should take into account the occupation of the Brazilian countryside in establishing the restrictions to which each of the country's properties and rural possessions will be subject.

Ruralists who have enough native vegetation to comply with the general rule of the new law should do so and it has not been possible since 28 July 2008 to reduce the presence of such vegetation in the PPA and LR. Producers who, before July 22,2008 , converted native vegetation areas to production areas in PPA or LR, are now required by transitional rules, requiring the introduction of minimum compensations and the productive activity maintained in the rest of protected areas, comply with soil and water conservation criteria.

This legal statute also requires all Brazilian rural properties to complete the Environmental Rural Registry (CAR, in Portuguese), which will provide all information related to the legal requirements established in the new law, having a 
period of 12 months to be completed since its availability by the Executive Power.

In PPA, in relation to the riverbank, it is established that the marginal ranges of any natural, perennial and intermittent watercourse, excluding ephemerals, from the edge of the regular bed, in minimum width for courses up to $10 \mathrm{~m}, 30 \mathrm{~m}$ is established; Courses from 10 to $50 \mathrm{~m}$ are established at $50 \mathrm{~m}$ width, in courses from 50 to $200 \mathrm{~m}$ the established width is $100 \mathrm{~m}$. For watercourses above $600 \mathrm{~m}$ the width of $500 \mathrm{~m}$ is stipulated.

In art. 10, a new wording was given to the figure of the socalled restricted use areas, which are comprised of wetlands, where ecologically sustainable ${ }^{3}$ exploration is allowed, taking into account the technical recommendations of the official research agencies, leaving new vegetation suppressions for alternative land use, subject to the authorization of the state environmental agency, based on the recommendations mentioned in that article.

It can be seen that in art. 11, which again appears the sustainable term, even in areas of inclination of 25 to 45을 being allowed under these conditions, the exercise of agrosilvipastoral activities. When the words economy and sustainability are combined in one sentence, the theory of living systems proposed by Ludwig von Bertalanffy is taken over, which aims to explain how the life of living beings can be better when it is based on the four basic concepts, which are: creation, maintenance, renovation and diversification. For this reason, the maintenance of the physical infrastructure associated with the development of the activities, be observed within the principle of technique, good agronomic practices, being forbidden to them the conversion of new areas, except the hypotheses of public interest and social interest.

Overall, the 2012 Forest Code corrects a number of inconsistencies introduced in the two previous codes, mainly because it creates a new instrument within the legislation, which is the Environmental Rural Registry (CAR), which is carried out with State or Municipal environmental agency, which must include the identification of the owner or owner of the rural property, proof of ownership or possession, identification of the property by means of a plan and descriptive memorial with information on the perimeter of the property, remaining areas of native vegetation, permanent preservation areas, restricted use areas, consolidated areas and, if applicable, location of the legal reserve, having the great advantage that confers a strategic planning character to the producer since after five years from the date of publication of Law no. 12,651 / 2012.

Provided for in Article 29 of the Law, it was created as an: "electronic public national registry, mandatory for all rural properties, in order to integrate the environmental information of rural properties and possessions, forming a database for control, monitoring, environmental and economic planning and combating deforestation".

The law also provides that the obligation to enroll in the CAR should preferably be made in the municipal and state environmental agencies when it should be required of the owner or rural owner (art. $29 \S 1$ ): their identification (as owner) ); proof of ownership or possession; and identification of the property by means of a plan and descriptive memorial, containing the indication of the geographical coordinates with at least one point of the perimeter of the property, informing the location of the remaining native vegetation, Permanent Preservation Areas, Areas of Restricted Us, the consolidated areas and, if any, also the location of the Legal Reserve.

Regarding the legal nature of the CAR, the law clearly provides that "registration will not be considered a title for the purpose of recognizing the right to property or possession, nor does it eliminate the need to comply with the provisions of art. 2 of Law No. 10,267 of August 28, 2001" $(29, \S 2)$, never being conceived as a land mechanism, but rather as a mechanism for environmental regularization. However, it has always been presupposed on the existence of a valid property or possession on which to register. However, in practice, this assumption has been set aside and, as a result, the CAR gradually becomes an instrument for land grabbing (Moreira, 2016). Financial institutions will only grant agricultural credit, in any of its modalities, to rural property owners who are registered with CAR.

\section{Conclusion}

Despite the evolution of the proposed law, some changes still need to be revised, as they are still based on economic interests and neglect the environmental character, and that even after the adoption of the new code, severe damage still exist, which requires greater commitment from regulators to enforce legislation.

Much still has to be evolved in environmental valuation and in view of the different scenarios experienced in agriculture and it is necessary to focus on sustainability and maintenance of biodiversity, in order to ensure the long-awaited quality of life for current and future generations.

\section{References}

Aquino RSL (1996). História das sociedades: das sociedades modernas às sociedades atuais. Ed. Ao Livro Técnico.

Arhens S. (2003) O "Novo" Código Florestal Brasileiro - Trabalho Voluntário apresentado no VIII Congresso Florestal Brasileiro, 25 a 28-08-2003, São Paulo, SP. São Paulo: Sociedade Brasileira de Silvicultura; Brasília: Sociedade Brasileira de Engenheiros Florestais, 1 CD-ROM.

Brasil (2012). Decreto Federal 23793/34; Lei n. 4.771/1965; Lei $12.651 / 2012$.

Costa EC, Costa MAC (2008) O princípio da precaução e o modelo de desenvolvimento econômico de alguns setores da produção primária: realidade ou utopia. 147 p. Editora Orium, Santa Maria - RS.

Costa EC, Oliveira RS de (2013) Meio ambiente e a agricultura no século XXI. 120 p. Editora Ithala, Santa Maria - RS.

D'Almeida CA (2012) Exploração ecologicamente correta?! Reflexões sobre as políticas bem estaristas do capitalismo verde. In: III Encontro Internacional de Ciências Sociais - Crise e Emergência de Novas Dinâmicas Sociais, Pelotas. II Encontro Internacional de Ciências Sociais - As Ciências Sociais e os Desafios do séc. XXI. Pelotas: Ed. Universitária UFPel, 3.

Farias T (2008) Responsabilidade civil em matéria ambiental: os danos materiais, os danos morais e o meio ambiente. Revista Dataveni 0(1): 1-18.

Guatari F (1990) As três ecologias Campinas, SP: Papirus.

Guimarães DT (2006). Código de Hamurabi 1ạ. Edição, Editora: Rideel São Paulo- SP 96p.

Lima GC (1997) O debate da sustentabilidade na sociedade insustentável, Revista Política \& Trabalho, 13: 201-222. 
Noll P (2009) A lei, o tempo e o direito. Revista Justiça e História 6(12): 1-16.

Pilla MCB (2009) A. Manuais de civilidade, modelo de civilização. História em Revista. Available at < http://www2.ufpel.edu.br/ich/ndh/downloads

/historia_em_revista_09_maria_pila.pdf > Accessed on: December 23, 2013.

Silva JAA, Nobre AD, Manzatto CV, Joly CA, Rodrigues RR, Skorupa LA, Nobre CA, Ahrens S, May PH, Sá TODA, Cunha MC, Rech Filho EL (2011) O Código Florestal e a Ciência: contribuições para o diálogo. São Paulo - SP: Sociedade Brasileira para o progresso da ciência, SBPC; Academia Brasileira de Ciências, ABC, 124 p.
Silva PE (2003) Vocabulário Jurídico 21a edição, Editora: Forense, Rio de Janeiro-RJ. 874p.

Simonetti MCL. (2011) A (in)sustentabilidade do desenvolvimento: Meio ambiente, agronegócio e movimentos sociais. 1a Edição. Editora Cultura acadêmica, Marília-SP. 